\title{
INTERNATIONAL TREATIES AND CANADIAN FEDERALISM: THE CASE OF CLIMATE CHANGE POLICY
}

\section{By Kristin Smith}

\section{Abstract}

Ce texte discute du rôle des gouvernements provinciaux dans le développement de la position canadienne en ce qui concerne les accords internationaux. En particulier, il considère la manière dont la structure fédérale du Canada affecte la négociation et l'exécution des traités internationaux et de la politique étrangère.

\section{Introduction}

The structures of Canadian federalism affect the processes and outcomes of many policy areas, including foreign policy. Canadian foreign policy is influenced by federalism when individual provinces attempt to become international actors, and through the negotiation and implementation of international treaties. The role of provincial governments in the development of the Canadian position in international agreements is the focus of the current study.

The influence of federal-provincial relations on the negotiation and implementation of international agreements varies between federal states such as Australia, Germany, the United States of America and Canada. In Canada, the prerogative of the federal government to negotiate and implement international treaties is constrained by provincial governments, on both an individual and 
holistic level. The ability of provincial governments to limit the federal government from following through on commitments made through international agreements has at times produced conflict between the two levels of government. Conflict and disagreement between the two levels of government has in many instances resulted in the inability of the federal government to fulfill international commitments to which it is a signatory. Such inaction in terms of the implementation of agreements can adversely affect the effectiveness and credibility of Canadian foreign policy on the international scene.

The policy area most reflective of provincial involvement in recent decades is the environment and, in particular, climate change policy. The environment is a shared area of constitutional authority requiring provincial responsibility for the implementation of commitments enshrined in international agreements. The Kyoto Protocol is the most recent and relevant example of the effect of federalism on Canadian international treaty-making. In the 1997 international negotiation of the Kyoto Protocol, the federal government affirmed its constitutional power to freely negotiate international treaties by abandoning the 'national consensus' adopted in consultations with the provinces prior to the international conference. In response to the federal government's unilateral action, the provinces have repeatedly flexed their power to control the implementation of the commitments in the agreement. Consequently, five years after the signing of the Accord, the disconnect between the federal and provincial governments has resulted in inaction and failure to implement the commitments. Such failure allows for an analysis of the effectiveness of international treaty-making in the Canadian federation, including the impacts of federalism on the credibility and legitimacy of Canadian foreign policy.

In order to analyze the effects of provincial involvement on the implementation of the Kyoto Protocol, the impact of federalism on the field of foreign affairs is examined. Since the responsibility for foreign affairs is unspecified in the Constitution Act, 1867, the evolution of the jurisdictional authority over international relations is discussed. In particular, emphasis is given to the impact of judicial decisions in the 1930's on establishing the role of each level of government in the field. In analyzing the impact of federalism on Canadian foreign affairs, focus is placed on the effect of the division of powers on international treaty-making. The necessity of striking an appropriate balance between the jurisdictional authorities of both levels of government in the policy area governed by an international agreement is examined. More importantly, the issues of credibility, legitimacy and effectiveness raised by the involvement of 
provincial governments in the implementation of international treaties is analysed in terms of the rising relevance of international affairs in an increasingly global and transborder world.

The role played by Canada in addressing the international issues associated with climate change is utilized as a case study of the impact of Canadian federalism on international treaties. Firstly, the evolution of the issue on the international agenda is outlined: the 1988 Toronto Conference which created the first demands for reductions in carbon dioxide emissions; the negotiation of the Framework Convention on Climate Change; the 1992 Rio Conference where climate change demands escalated to an international convention; the Conferences of Parties to analyze the progress of the framework convention; and the 1997 signing of the legally binding protocol in Kyoto. Secondly, the provincial motives underlying their involvement in climate change policy jurisdictional, economic and political - are discussed. Moreover, the Canadian position on climate change policy presented at various international conferences is examined in light of the continuous failure to honour the international commitments to which it acceded, in particular the recent Kyoto Protocol. The implications of such failure on the credibility and effectiveness of Canadian climate change policies and foreign policy more generally, are analyzed. Finally, a speculative analysis is performed regarding the probability of fulfillment of the commitments of the Kyoto Accord in light of the recent ratification without provincial support for implementation.

\section{Federalism and International Treaty-Making in Canada}

Federalism is commonly defined as a system of government wherein authority is divided between a central government and regional units, which are not subordinate but rather equal to each other. ${ }^{1}$ The written constitution of a federal state traditionally outlines the specific powers and responsibilities of each level of government, a residual clause, and a mechanism by which a level of government can ensure the protection against the invasion of its jurisdiction by another level. In the Canadian constitution the federal and provincial powers and responsibilities are enumerated in sections 91 and 92 respectively, the 
residual power is allocated to the central government through the Peace Order and Good Government clause, and the judiciary acts as the referee between the two levels of government.

Although it is not specifically mentioned in the Constitution Act, 1867, the responsibility for foreign affairs in a federal system is typically attributed to the central unit. Greg Caven illustrates various common understandings of the centrality of foreign affairs: "Wheare characterizes foreign affairs as one of the minimal powers of a federal government, while Davis comments that such matters as foreign relations have always formed the core of federal activity." The principal reason for associating the responsibility for foreign affairs with the central government is to ensure the articulation of a unified foreign policy in the international scene. However, the necessity of central attention to issues related to foreign affairs, including national defence, security, currency, and trade does not exclude participation on the part of subunits within the federation. The assumed allocation of responsibility for foreign affairs to the central government arguably infers a capacity to invade areas of exclusive jurisdiction of the subunits through the responsibility to negotiate and fulfill international agreements. Caven effectively illustrates the issues that arise from assigning exclusive authority for foreign affairs to the central government within a federation:

\footnotetext{
If a concern is felt to protect the units from excessive central government interference via the exercise of its power to enter international agreements, how is this to be achieved? Should a restraint be placed upon the range of agreements that may be made in the first place? Or should the capacity of the central government to implement international agreements $[\ldots]$ be limited to the same end? ${ }^{3}$
}

Thus, the power to negotiate international agreements in a federal state requires striking a balance between limiting the ability of the central government to utilize its authority to govern in areas outside its jurisdictional authority; and to ensure restrictions placed on its power do not undermine the credibility of a unified position on the international scene.

In Canada, decisions by the judiciary attempted to achieve two objectives. The first was to assign a responsibility for foreign affairs unallocated in the 
constitution. The second was to create a necessary balance between upholding the ability to articulate a credible foreign policy and limit the federal government from using its power to influence exclusive provincial jurisdiction. Decisions by the Judicial Committee of the Privy Council (JCPC) ${ }^{4}$ in the 1930's fundamentally contributed to defining the international treaty-making power in Canada and the legislative capacity to implement such treaties. The reasons for failure to explicitly assign authority over foreign affairs in the Constitution Act, 1867, are understood by reference to the status of the country at Confederation. Canada was a colony of the British Empire, leaving responsibility for international relations in the hands of the imperial government. Caven explains: "the only directly relevant provision inserted into the British North America Act was section 132, which allowed the federal government to make laws implementing in Canada treaties made by the British Empire [...] this provision conferred no power upon any Canadian authority to make and implement treaties on its own behalf." ${ }^{5}$ However, the assumed authority of the executive government to negotiate and implement international treaties grew as Canada increasingly gained independence from the British Empire. The provinces opposed the ability of the federal government to negotiate and implement international treaties in all policy areas, particularly exclusive provincial jurisdiction. The unsettled nature of the power over treaty-making led the judiciary to review the division of powers associated with the international treaty-making process.

Three court cases in particular rendered decisions which "established the basic terms of engagement." In 1932, the Aeronautics Case rendered the first significant decision. The JCPC upheld the prerogative of the federal government to implement a treaty of the British Empire established by section 132 of the Constitution Act, 1867. Thus, the federal government was granted unilateral authority over implementation of international treaties negotiated by Britain, regardless of provincial jurisdiction in the area in question. In the same year, the provinces argued in the Radio Case that the federal government had acted ultra vires (outside) its jurisdictional authority by signing an international agreement regarding broadcasting regulations. Distinguished from the Aeronautics Case, the Radio Case involved a treaty signed by the federal government, not the Empire, thus section 132 did not apply. "The JCPC ruled broadcasting was not specifically assigned to the provinces and Ottawa had the 
rights to implement [the treaty] under the residual powers of section 91."7 Therefore, both Radio Cases granted the federal government the power to implement international treaties which fell under Peace, Order and Good Government.

The third significant case granted the provinces the ability to constrain and limit the federal government's unfettered treaty-making power to ensure the protection of their exclusive jurisdiction. The Labour Conventions Case of 1937 ruled that "the federal government could not enact legislation in an area explicitly given to the provinces under section 92, even if it was designed to fulfill obligations under an international treaty." Caven explains the result of the decision: "in areas of provincial competence, while the Canadian government can make a treaty, it cannot effectuate it through legislative implementation." The decision in the 1937 case set a precedent to govern the actions of both levels of government within the international treaty-making process. Since the ruling, the provinces have seized numerous opportunities to flex their authority over the implementation of treaties in provincial jurisdiction. One of the areas in which the provinces have exerted the most force and influence is climate change policy.

\section{Climate Change policy and Ganadian federalism}

\section{The EVolution of AN INTERNATIONAL ISSUE}

Climate change and global warming issues were first given attention as a part of an international wave of environmental advocacy in the late 1970's and early 1980's. The first World Climate Conference was held in Geneva in 1979 and a subsequent conference was held in 1985 to analyze "the role of greenhouse gases on climate change." 10 The definitions of 'climate change' and 'global warming' presented by Paul Halucha will be adopted: "Climate change refers to the long-term change in the earth's climate brought about by alterations in the global atmosphere due to human activity [...] Global warming is therefore a 
consequence of the elevation of atmospheric concentrations in greenhouse gases." The international implications of the issue, which enticed attention at the international level, are evident: "Greenhouse gas emissions have multiple sources that are not isolated to the activities of one state. Climate change is a global issue that requires global action." "12 The early international conferences regarding the matter served the purpose of drawing attention to the issue of global warming and presenting policy options to stabilize and decrease emission levels. However, the international community did not actively consider setting quantitative emission reduction targets until 1988. In that year, the issue of climate change became a pressing reality because of the record-breaking heat wave during the summer. Consequently, the international conference held in Toronto prioritized the issue on the international policy agenda. Although the primary significance of the Toronto Conference can be viewed in terms of the international attention it drew to the seriousness of climate change, the Conference also set the term of reference for emission reductions. "The Conference called for urgent measures to reduce emissions of carbon dioxide [...] by 20 percent by the year 2005." "13 However, the success of the Conference was quickly overshadowed by a lack of action on behalf of signatory governments to implement the commitments.

The attention gained from the 1988 conference propelled the international community to embark upon formal negotiations for the development of a Framework Convention on Climate Change (FCCC). Negotiations proceeded in 1991 and 1992 and the framework was presented for signing at the 1992 United Nations Conference on Environment and Development (UNCED) - the Rio Conference. Although the FCCC made a significant achievement by focusing attention on the need for a larger commitment to emissions reductions, the framework did not mention implementation. Thus, the agreement left implementation strategies within the hands of national governments. As Heather A. Smith explains: "As an international instrument it [the FCCC] did not provide much pressure for states to meet their commitments."14 The first Conference of Parties (COP) to assess the progress of the commitments of the FCCC was held in 1995. The conclusion reached at the Conference was that emission targets had not been reached by the majority of states included in the FCCC and the parties developed a commitment to create a legally binding protocol by the third COP in 1997. The first legally binding protocol was negotiated in Kyoto in 
1997. The protocol compelled signatories to reduce emission of greenhouse gases by 6 percent from 1990 levels by 2008-2012. ${ }^{15}$ Since the provinces are a key player in the Canadian position on climate change, an analysis is performed on the role of the provinces in the policy area, prior to outlining Canadian action (or inaction) to meet international commitments.

\section{Provincial Involvement}

Since climate change policy is an internationally defined issue, the reasons for provincial involvement in the area are closely related to the motives associated with their involvement in international relations. Feldman and Feldman outline the numerous internal and external reasons for provincial participation in foreign affairs: "Provincial governments engage in international relations because they have the bureaucratic and fiscal wherewithal, the formal opportunity, the jurisdictional obligation, or the political and economic necessity." Smith defines provincial participation in the international scene "as the protection, and projection, of their interests." ${ }^{17}$ With regard to climate change policy in particular, provincial involvement is primarily directed as the protection of exclusive jurisdiction, and secondarily in terms of economic interests. Moreover, the increasing politicization of the issue gave rise to a third reason for provincial involvement, the protection of political interests amid unilateral federal action.

The Canadian constitution is rather ambiguous regarding the allocation of jurisdictional responsibility for environmental matters. Patrick Farfard outlines the enumerated powers of each level of government, which mandate a constitutional authority, to act in environmental policy:

\footnotetext{
Provinces legislate in the area of the environment based on their constitutional responsibilities for such things as local works and undertakings, property and civil rights, and the management of natural resources [...] federal environmental legislation is based on varying combinations of the federal trade and commerce power, federal responsibility for the fishery and the conduct of international relations. ${ }^{18}$
}

In a specific reference to climate change policy, actions to mitigate against the 
effects of global warming are directly related to the provincial jurisdiction over non-renewable resources, the most significant of which is energy resources. The role of the federal government in climate change is mandated by the international attention accorded to the issue. Thus, it is clear that climate change policy is an area of shared jurisdiction, requiring cooperation between the two levels of government. The necessity of cooperation is intensified as a result of the widespread internationalization of climate change policy. As David Runnalls explains, "international initiatives [in environmental policy] will continue to be negotiated by the federal government, but the provinces will continue to be responsible for implementation [...] obtaining provincial agreement to their implementation will involve the development of new techniques of federal / provincial cooperation." ${ }^{\prime 19}$ The implications of shared jurisdictional authority and the requisite cooperation on the effectiveness and credibility of Canada's international position on climate change policy is analyzed in the subsequent section.

As the international pressure and attention surrounding environmental issues grew in the 1980's, it also became evident that environmental issues are clearly interlinked with economic policy. The early hesitation at both the domestic and international level to take action regarding climate change policy stands as evidence that economic concerns were and continue to be paramount to environmental protection. In two separate articles examining Canadian climate change policy, Smith asserts the pronounced importance of economic interests: "at the heart of this issue, for all orders of government, is economic viability." Furthermore, in a coauthored article, Douglas Macdonald and Smith affirm that environmental concerns routinely take second stage to economic concerns in both domestic and international negotiations on climate change policy. ${ }^{21}$ Provincial concerns regarding the protection and projection of economic interests are most strongly articulated as a result of the indisputable connection between climate change initiatives and energy policy. The reduction of carbon dioxide emissions - the central aspect of international commitments to mitigate against global warming - is aggressively opposed by strong industrial-producing provinces, since the reductions in energy use would have significant economic consequences. "Significant reductions in energy use are perceived to have major impacts on domestic and international economic performance." ${ }^{22}$ Although the economic impact of climate change policies is difficult to accurately quantify, 
econometric models have been utilized to provide political decision-makers with an estimated cost of action and/or inaction. Halucha claims that "one undeniable contribution of economic modelling has been to confirm for governments the seriousness of Kyoto commitments. There would be economic costs involved with implementation, and failure to meet commitments would have both political and economic repercussions. ${ }^{23}$ Thus, the apparent link between environmental and economic policies ensure that the protection of individual economies remain a key objective for provincial involvement in climate change policy.

As climate change policy became prioritized on the international agenda, the politicization of the issue was an evident development. In Canada, climate change is a highly political issue because of the shared jurisdiction between the two levels of government. The federal government has repeatedly protected its prerogative to negotiate international treaties that define the international initiatives to lessen the effects of global warming. Such determination to speak for Canada on the international scene has led the federal government to act unilaterally in spite of provincial jurisdiction and authority over the implementation of policies in the area. The federal government's insistence on acting independently created political consequences by straining relations with provincial governments, and as a result, constraining the ability to implement the international commitments. Thus, the intensification of federal-provincial conflict by way of federal unilateral initiatives and a lack of willingness to uphold the national consensus has politicized the issue and created political motives for provincial opposition against implementation of the international agreement.

\section{The Canadian Position on Climate Change}

Canada assumed a leadership role in the early international conferences on climate change, in particular the Toronto Conference. However, the enthusiasm and leadership projected by Canada on the international scene was not matched by aggressive action to implement the commitments at the domestic level. The lack of action at the domestic level is partly a consequence of provincial involvement in the area. ${ }^{24}$ The fact that climate change falls under provincial jurisdiction explains the provincial affirmation of involvement from the outset in 
the late 1980's. Following the Toronto Conference in 1988, a national action strategy was developed between the provinces and the federal government. The strategy addressed the importance of provincial power to implement international treaties in climate change policy. As Smith explains, the provinces utilized the strategy as "a signal to the federal government that provincial jurisdiction in the area of implementation was not to be ignored." 25 Following the 1992 Rio Conference, federal and provincial energy and environment ministers began to negotiate a National Action Plan on Climate Change (NAPCC). Throughout the negotiations, Alberta made it clear that it would only consider the adoption of voluntary mechanisms for compliance. Thus, the central component of the NAPCC was the Voluntary Challenge Registry, ensuring that altruism rather than coercive instruments would be adopted to implement the policies. ${ }^{26}$ The NAPCC was viewed as adopting a 'national consensus' to climate change policy. Such national consensus commonly reflects the lowest common denominator, which can lead one to question the effectiveness of the policies as a means of achieving the environmental objectives at issue. However, developing a Canadian position reflective of the national consensus is imperative since provincial governments have power over implementation. The reality of the constitutional division of powers in the policy area is that without a 'national' implementation strategy, including both federal and provincial agreement, it will remain doubtful that international commitments will be met.

In the weeks preceding the 1997 Kyoto Conference, the governments attempted to develop a Canadian position reflective of the national consensus. Federal-provincial consultations ensued on two fronts: a meeting took place between the Canadian Council of Ministers of the Environment (CCME), as well as a Joint Energy and Environment Ministers Meeting (JMM). The negotiations of the JMM produced a consensus that "'it was reasonable to reduce aggregate greenhouse gas emissions in Canada back to 1990 levels by 2010.",27 Although the position adopted at this mid-November meeting was declared the national consensus, it was not the final Canadian negotiating position. The federal government was determined to present a position at the international conference superior to the position of the United States of America. ${ }^{28}$ By asserting its authority to freely negotiate international treaties for Canada, the Prime Minister abandoned the national consensus both prior to and in the final signing of the 
Kyoto Protocol.

On 3 December 1997, Prime Minister Chrétien announced that the Canadian position was to demand a three percent reduction below 1990 levels. However, at the conclusion of the conference a week later, the Prime Minister committed Canada to reduce emission levels by six percent. The implications of signing an international agreement inconsistent with the national consensus are widespread. The most notable of these is the reduced probability that the commitments will be implemented. Provincial Premiers immediately criticized the unilateral actions of the federal government at the international conference. Alberta Premier Ralph Klein declared the actions of the federal government at Kyoto as "not acceptable, this accord in no way reflects the Canadian position that was established in Regina." 29 As a result of the provincial opposition to the commitments made by the federal government at Kyoto, action was not taken to implement the accord. Instead, the federal and provincial governments decided to examine the costs of ratification and possible strategies for implementation. Thus, as in the case of the commitments made at the 1992 Rio Conference, it remained doubtful that Canada would honour the emissions reduction target it had agreed to in the international treaty.

The failure of Canada to implement the numerous international commitments to address climate change raises numerous questions regarding both the effectiveness of the policies in achieving the environmental objectives, and the international credibility of the Canadian position. The strong provincial opposition to implementation ensured that both the international commitments to reduce emission levels negotiated in 1992 and in 1997 are unfulfilled to date. By failing to breathe life into the commitments, the effectiveness of the emission reductions to mitigate against climate change have been nil. Furthermore, the credibility of the Canadian position within the international community is questioned. MacDonald and Smith claim that "the credibility of Canadian diplomacy and future initiatives cannot help but be affected" by the failure to meet the emission targets of the Kyoto accord. ${ }^{30}$ Directly related to the credibility of the Canadian position is the legitimacy and authority accorded to any future climate change initiatives. The federal government has arguably lost claims to legitimacy and authority over Canadian climate change policy because of the failure to meet the international targets to which it has repeatedly 
committed.

Climate change policy is illustrative of the influence of federalism on Canadian international treaty-making. As an area of shared jurisdictional authority under the Canadian constitution, the federal government holds the power to independently negotiate international treaties, but the provinces are responsible for implementation. This disconnect in authority necessitates fundamental federal-provincial cooperation to ensure the fulfillment of international commitments at the domestic level. In terms of international treaties regarding climate change, the federal government has exercised its prerogative to freely negotiate international treaties, and on various occasions abandoned the 'national consensus' in signing agreements. The consequences of federal unilateral action are widespread provincial opposition to the agreement and a failure to implement the commitments. Such failure invokes an adverse impact on the effectiveness and credibility attributed to the Canadian position on climate change.

This paper has analyzed the Kyoto Protocol as the most recent manifestation of the failure to implement an international treaty signed by the federal government in an area of provincial jurisdiction. In the fall of 2002, Prime Minister Chrétien announced that Kyoto would be ratified by year end. Pervasive provincial opposition ensued, arousing speculation that ratification would proceed. As a procedure, ratification merely requires approval by the cabinet through an order-in-council. Thus, opposition from business and industry stakeholders, opposition parties, and the provinces technically cannot impede ratification. Throughout the fall of 2002, the provinces remained ardently opposed to the implementation of the commitments of the 1997 Accord and advocated a "made-in-Canada" approach to emissions reduction. Numerous federal-provincial meetings attempted to negotiate and develop an implementation strategy. However, provincial refusal to incur economic damage as a result of climate change policy, and the hard-lined approach of the Prime Minister, who refused to concede to any provincial demands, hindered the development of an agreement on implementation. Irrespective of the failed 
negotiation of a federal-provincial implementation plan, the federal government proceeded to ratify the Kyoto Protocol on December $10^{\text {th }} 2002$.

The implications of the recent ratification on the implementation of initiatives to reduce carbon dioxide emissions in Candida are insignificant. The media has described ratification as an "empty act" and asserted that "Kyoto ratification without implementation is largely a symbolic exercise."31 Without federal-provincial agreement for implementation, the commitments made by Canada in the five year old agreement will continue to be left unfilled.

Canada's failure to fulfill numerous international commitments to climate change has implications for Canadian foreign policy in general. The loss of credibility associated with the Canadian position on climate change as a result of the neglect to implement treaties can transfer to other areas of government policy. The rising interdependency and transborder nature of policy areas has increased the propensity for issues to be addressed at the global level. The repeated failure to implement climate change initiatives raises the question of whether international commitments made by Canadian diplomats in other policy areas can be considered credible by international actors. Climate change policy can be viewed as initiating a slippery slope in terms of Canada's credibility and authority in the international community with the outstanding possibility of greater consequences in other policy areas.

\section{Endnotes}

${ }^{1}$ Wheare 2.

${ }^{2}$ Caven 10.

${ }^{3}$ Ibid. 11. 
${ }^{4}$ The JCPC was the final court of appeal for the colonies of the British Empire. Although the Supreme Court of Canada was created in 1875, the JCPC continued to act as the final appellant court for Canada. It served this role in Canada until constitutional amendment in 1949 mandated the Supreme Court of Canada as the final and exclusive court of appeal.

${ }^{5}$ Caven 13.

${ }^{6}$ Smith 6.

${ }^{7}$ Ibid. 6.

${ }^{8}$ Quoted in Ibid.

${ }^{9}$ Caven 14.

${ }^{10}$ Halucha 288.

${ }^{11}$ Ibid. 288.

${ }^{12}$ MacDonald and Smith 109.

${ }^{13}$ Runnalls 135.

${ }^{14}$ Smith 150.

${ }^{15}$ Ibid. 5.

${ }^{16}$ Michelmann and Soldatos 177. 
${ }^{17}$ Smith 6.

${ }^{18}$ Farfard 205.

${ }^{19}$ Runnals 150.

${ }^{20}$ Smith 5 .

${ }^{21}$ MacDonald et al. 122.

${ }^{22}$ Ibid. 5.

${ }^{23}$ Halucha 122.

${ }^{24}$ Major business interests also complained about the uneven impact of meeting the cost of reducing carbon dioxide emissions between businesses, some be adversely affected than others. The opposition of the private businesses, especially the industry sector, could have created significant impediments to implementation, even if the provinces did not raise opposition to climate change policy.

${ }^{25}$ Smith 7.

${ }^{26}$ MacDonald et al. 112.

${ }^{27}$ Quoted in Halucha 299.

${ }^{28}$ MacDonald et al. 114.

${ }^{29}$ Quoted in Smith 9. 
${ }^{30}$ MacDonald et al. 124.

31 "Don't rush to ratify without a Kyoto plan." The Globe and Mail.

\section{BIBLIOGRAPHY}

Caven, Greg. "Federal Constitutions and External Relations" Foreign Relations and Federal States. Ed. Brian Hocking. London: Leicester University Press, 1993. 9-26.

Chase, Steven and John Ibbitson and Robert Matas. "Ottawa to brush aside provinces' Kyoto concerns," The Globe and Mail, 16 November 2002, $<$ www.globeandmail.com $>$.

Chase, Steven. "Don't rush to ratify without a Kyoto plan." The Globe and Mail. 9 November 2002. <www.globeandmail.com>.

Dunfield, Allison. "Kyoto protocol ratified," The Globe and Mail, 10 December 2002, <www.globeandmail.com>.

Farfard, Patrick. "Green Harmonization: The Success and Failure of Recent Environmental Intergovernmental Relations." Canada: the State of the Federation 1997: Non-Constitutional Renewal. Ed. Harvey Lazar. Kingston: Institute of Intergovernmental Relations, Queen's University, 1997. 203-227.

Greenspon, Edward. "Provinces let down at Kyoto, Klein says deal on emissions 'not acceptable," The Globe and Mail, 12 December 1997: A1.

Government of Canada. A Discussion Paper on Canada's Contribution to 
Addressing Climate Change. 14 May 2002.

Halucha, Paul. "Climate Change Politics and the Pursuit of National Interests." Canada Among Nations 1998: Leadership and Dialogue. Ed. Fen Osler Hampson and Maureen Appel Molot. Toronto: Oxford University Press, 1998. 285-304.

Hocking, Brian. Foreign Relations and Federal States. London: Leicester University Press, 1993. . Localizing Foreign Policy: Non-Central Governments and Multilayered Diplomacy. New York: St. Martin's Press, 1993.

Joint Meeting of Energy and Environment Ministers. "Federal, Provincial and Territorial Ministers of Energy and Environment Discuss Climate Change." News Release. 21 May 2002.

MacDonald, Douglas and Heather A. Smith. "Promise made, promises broken: Questioning Canada's Commitments to Climate Change." International Journal 55.1 (1999-2000): 107-124.

Mahoney, Jill and Steven Chase. "Klein lays Kyoto-battle groundwork." The Globe and Mail. 20 November 2002. <www.globeandmail.com>.

McCarthy, Shawn. "Hamm cites progress on Kyoto." The Globe and Mail. 11 November 2002. <www.globeandmail.com>.

Michelmann, Hans J. and Panayotis Soldatos. Federalism and International Relations: The Role of Subnational Units. Oxford: Clarendon Press, 1990.

Natural Resources Canada and Environment Canada. "Anderson and Dhaliwal Welcome Constructive Provincial/Territorial Input into Draft Climate Change 
Plan.” News Release. 28 October 2002.

Provincial-Territorial Energy and Environment Ministers. Provincial and Territorial Statement on Climate Change Policy. 28 October 2002.

Reif, Linda C. "Environmental Policy: the Rio Summit Five Years Later." Canada Among Nations 1998: Leadership and Dialogue. Ed. Fen Osler Hampson and Maureen Appel Molot. Toronto: Oxford University Press, 1998. 267-284.

Runnalls, David. "The Road from Rio." Canada Among Nations 1993-94:

Global Jeopardy. Ed. Christopher J. Maule and Fen Osler Hampson. Ottawa: Carleton University Press, 1993. 133-153.

Simpson, Jeffrey. "Between a Rock and a hard place." The Globe and Mail. 16 November 2002. <www.globeandmail.com>.

Smith, Heather A. Canadian Federalism and International Environmental Policy Making: The Case of Climate Change. Working Paper. Kingston: Institute of Intergovernmental Relations, Queen's University, 1998.

Smith, Heather A. "The Provinces and Canadian Climate Change Policy." Policy Options (May 1998): 28-30.

“Kyoto, Thumbs Up or Down.” Policy Options 24.1 (December 2002-January 2003).

Wheare, K.C. Federal Government_ $4^{\text {th }}$ ed. London: Oxford University Press, 1963.

Winfield, Mark S. "Environmental Policy and Federalism." Canadian Federalism: Performance, Effectiveness and Legitimacy. Ed. Herman Bakvis 